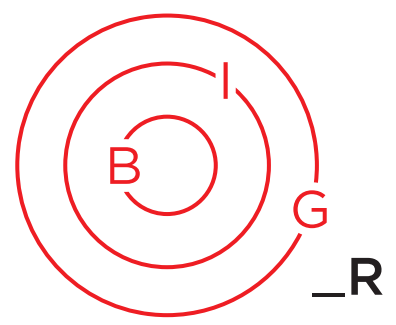

BOOK REVIEW

\title{
Vanishing Act: Review of The Book of Disappearance
}

\author{
Tonia Harris *
}

\author{
The Book of Disappearance: A Novel \\ By Ibtisam Azem \\ Translated from Arabic by Sinan Antoon \\ Syracuse NY: Syracuse University Press \\ 2019 \\ Paperback, 256 pages \\ ISBN: 9780815611110 \\ https://press.syr.edu/supressbooks/100/ \\ the-book-of-disappearance/
}

In a skillful blend of magical realism and speculative fiction, Ibtisam Azem's novel, The Book of Disappearance, exposes Palestinian memory and experience through the sudden disappearance of Palestinians from Israel. Azem asks us to consider what might happen if Palestinians vanished suddenly from Israel-without warning or explanation. The story is chronicled through Ariel, an Israeli journalist, as he navigates an anxious Tel Aviv and waits for his friend Alaa, one of the disappeared, to return. Ariel finds Alaa's notebook and unravels the threads of Palestinian existence through Alaa's eyes. What emerges is an enthralling story in which the Palestinian experience is illuminated through their unresolved disappearance.

Although he vanishes early in the story, Alaa firmly inhabits the pages of the novel through his journal containing recollections of Jaffa, a Palestinian-inhabited section of Tel Aviv, memories of his childhood, and intimate details about his relationship with his parents. It is also a memorial to his grandmother who was a

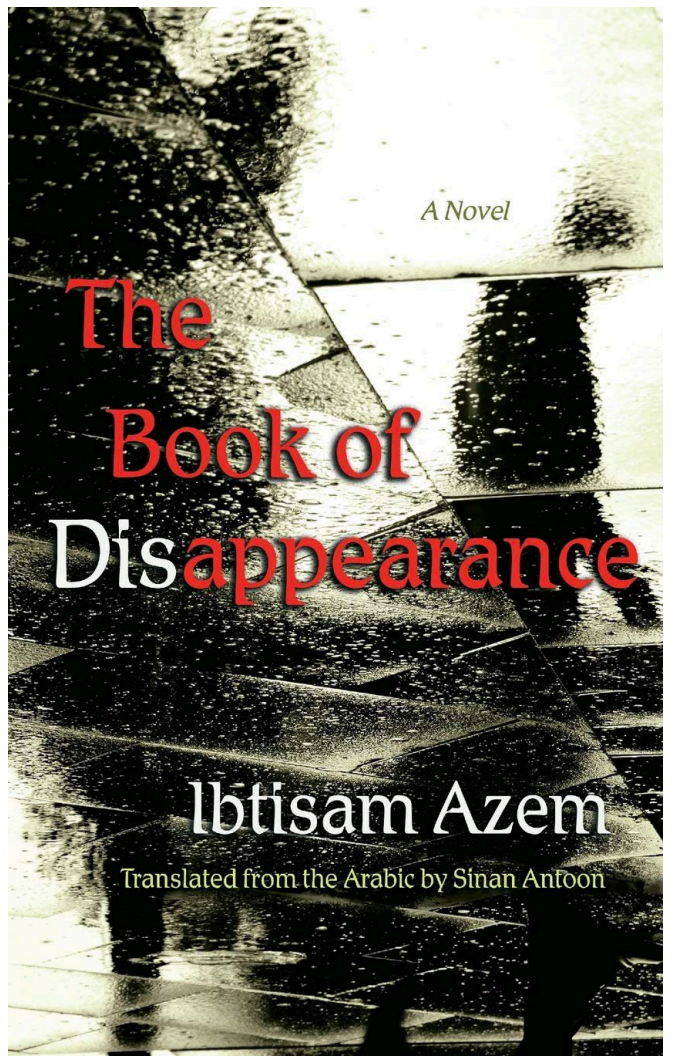

survivor of the nakba, the forced exodus that displaced over 700,000 Palestinian Arabs from their homes in 1948. Alaa writes that his grandmother's memory "is engraved in my mind," "a burden that pains me." Recording his grandmother's stories of the nakba, despite the pain it evokes, underscores scholar Nur Masalha's argument that narratives of memory contribute to the formation of collective identity (2012).

* Tonia Harris (she/her) is a Master of Arts student in the Department of English and Film Studies at the University of Alberta. Email: tonia.harris@ualberta.ca Twitter: @harris tonia 
Indeed, Alaa writes: "I carved my stories, yours, and those of others who are like us, inside me. We inherit memory the way we inherit the color of our eyes and skin." The archiving of Palestinian memory challenges Israel's founding father, David Ben-Gurion, who once said of the exiled Palestinians: "The old will die and the young will forget." Alaa's journal is thus the embodied, inherited memory of the nakba generation, as told by the voice of a younger generation that cannot forget, and for whom memory is their "last lifeline."

As the novel progresses without any news of the Palestinians' whereabouts, nor any sign of their return, Israelis decide en masse to claim residences that have suddenly been vacated. Similarly, Alaa's journal also becomes a space inhabited and claimed by Ariel. Crossing the border from outside to inner observer, Ariel's reading of the journal highlights border poetics scholar Johan Schimanski's theory that reading is a form of continuous border crossing (2015). The novel employs borders as textual and fluid spaces, where the linear border is symbolized by the written lines of the journal. The border is made fluid as Ariel reads the text and crosses into Alaa's memory, much like he crosses over the threshold of Alaa's apartment and begins living in Alaa's private space. The journal transforms into a public domain as Ariel consumes it page by page and translates passages into Hebrew, making plans to publish it later for a wider audience.

The novel's complexity is tightly wound through one character's witnessing of another's tragic past. We learn that Ariel's grandfather was an early Zionist settler in Tel Aviv and helped "build this miraculous western country in the heart of a backward east," establishing a city that "arose out of nothing;" yet, he won't call his grandfather a colonizer "even if there is a resemblance." There is a palpable tension between Ariel's settler roots and Alaa's inherited displacement: the building projects of the colonists erupted on top of Palestinian homes and lives to such an extent that, writes Alaa: "there was another city on top of the one we live in, donning it." Border theorists argue that bordering is the act of "tracing traces:" lines and markers imposed on top of other lines and markers. Other theorists describe the border as a suture, knitting together the domestic "inside" with the worldly "outside," resulting in a scar that makes border performance visible. For Alaa, however, the scar never heals: "Staying here means bleeding and living with an open and gushing wound." The city on top of city in which Palestinians inhabit transforms them into ghosts, writes Alaa, making their disappearance ever more apparent.
The chapters in the novel take the reader effortlessly between Alaa's journal; short vignettes illustrating the impact of the vanished population on Israeli businesses and services, and Ariel's activities while waiting for the Palestinians to reveal themselves. Ibtisam Azem succeeds in blurring and dismantling borders through the mystery of the disappearance and the subsequent forced waiting endured by the Israelis. The author reminds us that Israel is a deeply militaristic country obsessed with securing its borders; this is reinforced by Israelis in the novel praising their "brave soldiers who carried out a clean operation" and that Palestinians were "a problem that we finally managed to solve." But as Ariel discovers, neither the Israeli government nor the Israeli Defense Forces know where the Palestinians have gone and who might be responsible for their removal. Control is decidedly not in the hands of the state where it normally resides; the constant surveillance of Palestinian bodies is abruptly halted. Ariel notes in one of his articles: "Israelis are not that interested in the daily lives of Palestinians." Yet, Israeli interest in Palestinian whereabouts is precisely the experience that Azem lays bare for us in her novel, and it is exactly why Ariel continues to read Alaa's journal and wait in Alaa's apartment for him to return. Ariel admits that "waiting is hellish, but it is the only option." He now finds himself in a situation that echoes the torment of those who are stopped every day at border checkpoints and who still wait for their homes to be returned to them. The story emphasizes the state's use of borders to control both humans and landscape, suggesting, as scholar Anssi Paasi notes, that belonging to a state is defined by borders of inclusion and exclusion (2012).

The careful weaving of Alaa's history and Ariel's present makes The Book of Disappearance an engaging novel, one that takes the reader on a journey across borders into Palestinian memory and a lived experience of displacement.

\section{Works Cited}

Masalha, Nur. 2012. The Palestine Nakba: Decolonising History, Narrating the Subaltern, Reclaiming Memory. Zed Books.

Paasi, Anssi. 2012. "A Border Theory: An Unattainable Dream or a Realistic Aim for Border Scholars?" in Doris Wastl-Walter (ed.) The Ashgate Research Companion to Border Studies. Routledge. 11-31.

Schimanski, Johan. 2015. "Reading borders and reading as crossing borders" Borders and the Changing Boundaries of Knowledge 22: 91-107. 